\title{
CUSTOMER LOYALTY CHARACTERISTICS IN OBSTACLES OF INTERNET BANKING ADOPTIONS
}

\author{
Ronny \\ STIE Perbanas Surabaya, Indonesia \\ E-mail: ronny@perbanas.ac.id
}

\begin{abstract}
This paper analyzes the characteristics of customer loyalty on the barriers in using internet banking with a qualitative approach through interviews to 10 informants who have or never used internet banking. Three types of obstacles perceived by customers include security threats, difficulty in operating internet banking, and unreliable access. There are three characteristics of customer loyalty in the face of these barriers, first, leaving internet banking categorized as low loyalty; second, limiting themselves using internet banking features categorized as medium loyalty; and third, finding solutions to overcome barriers categorized as high loyalty. The three characteristics motivated by 3 factors including customer knowledge, risk perception, and influence of other service choices.
\end{abstract}

\section{KEY WORDS}

Internet banking, loyalty, adoption, customer knowledge, risk perception.

Information technology in banking is one of the most important resources to improve customer service and satisfaction, as a tool that enables banks to serve better and compete in the banking industry. The main function of information technology is to collect, process, and distribute electronic information and support electronic transactions related to customer fund management.

Better service quality is the reason for bank to use information technology such as internet banking (Waithaka, 2015). Internet banking transactions can improve the ability of customers in making transactions, without being limited distance with the flexibility of transaction time every day 24 hours. Internet banking transactions are non-cash transactions with better security than traditional transactions, as customers do not have to carry cash in cash at risk of theft.

The advantages of internet banking are not only on the availability of service features relevant to the needs of customers, but also how the bank as an internet banking provider able to overcome and reduce the barriers perceived by their customers in using internet banking. Research conducted by Munusamy et al (2012), Aslam et al (2011), Agwu (2015) reveals several factors that become obstacles of customers in adopting internet banking such as complexity, operational difficulties, risk, security and privacy. Basically, these barriers are related to the level of ease of using internet banking, data security and electronic system security, as well as internet banking reliability that should be able to operate properly and available at all times.

\section{LITERATURE REVIEW}

The adoption of internet banking is a form of customer acceptance of electronic information and bank transactions (Al-Fahim, 2013), and the willingness of customers to use the bank's website (Saeidipour, 2013). Some internet banking research uses Technology Acceptance Model (Davis, 1986) as the theory in internet banking adoption research is Perkins and Annan (2013), Eze (2011), Lee (2008), Al-Smadi (2012). In Technology Acceptance Model, the word 'Adoption' is not used. Instead, the term 'Actual System Use' is used, ie the use of the system. In this study, internet banking adoption is intended as the use of bank website by customers. 
Internet banking is one of the e-services. This is an online service that offers customers to be able to manage their own money saved in the bank. Nevertheless, customers can face various barriers that influence internet banking adoption as Munusamy et al (2012), Aslam et al (2011), Agwu (2015) have examined.

Munusamy et al (2012) examines the perceptions of customers regarding barriers to innovative technology-based products and services based on technology such as internet banking. There are 5 variables studied including perception of complexity, perception of operational difficulties, perception of risk, perception of high connection cost, and perception of inefficiency. Munusamy et al (2012) indicates that all variables categorized as obstacles have a significant effect on internet banking usage. Some customers have a negative image of internet banking channel that is perceived to be complex and difficult to use so that the use of internet banking services is limited. Difficulty in operating internet banking is especially faced by novice customers. They feel worried of clicking the false buttons that creates panic. Customers can perceive new technology as a threatening service and they reject it, lowering their interest in adopting internet banking, especially privacy threats. According to Munusamy et al (2012), there is no tolerance of unreliable internet banking services that may lead to distrust of customers, such as inaccurate data or the occurrence of 'Phishing' crimes in which personal data of the customer is accessible to unauthorized persons remotely without going through password security and username.

Aslam et al (2011) recommends to banks to develop internet banking after testing the barriers in internet banking adoption by active Internet users in Pakistan. Data were collected from 520 bank customers using internet banking services. The results indicates that security, privacy and high risk factors, lack of customer knowledge about the benefits of internet banking, the communication gap of customers and banks are significant barriers affecting internet banking adoption. Aslam et al (2011) advises to make bank communication channels effective in explaining the benefits of internet banking to customers, building better interpersonal relationships, one-to-one relationships, banks to customers. Aslam et al (2011) argues that bank performance is good if the storage of transaction data is safe and accurate, including safeguarding personal data of customers.

Agwu (2015) examines the barriers in adopting internet banking to explore the reasons for users as well as non-users of internet banking in Nigeria. The model theory used is Technology Acceptance Model (TAM), a model that has been used to explain consumer intentions using technology. The study show that security, privacy and infrastructure are the factors that significantly influence internet banking adoption. Customers can perceive security risks as an obstacle factor in the use of internet banking. Customers associate security risks with loss of money and are influenced by information from the media, in addition to customer concerns over security disturbances due to errors that occur in internet banking. Concerns over these security threats may diminish in the minds of consumers when consumers are aware of the many benefits gained when adopting internet banking.

\section{METHODS OF RESEARCH}

This study uses a qualitative approach. Data collection was performed with structured interview method to understand the factors shaping the behavior of customers against barriers in using internet banking. The data were obtained from primary sources, ie bank customer informants in Indonesia who still or have never adopted internet banking. Questions are raised regarding the obstacles experienced, informed decisions and actions facing these obstacles. The confidentiality of the identity of the informant is kept confidential, thus this paper the anonymous identity is used as informant 1,2 , and so on.

A pilot study was used in this study on 3 informants. Pilot study is intended to test the interview questions to assess the ability of informants to understand the intentions of interview questions. Additions and improvements to the questions were made to deepen the answer to the research problem. 
Data analysis in this research is content analysis: Data collection; Focus on analysis; Information Categorization; Identify patterns between categories; and pattern interpretation between categories.

Ten informants were interviewed both directly and via telephone. These ten informants are still or have never adopted internet banking. Informant characteristics are aged 24 - 55 years old, employment, lecturers, and entrepreneurs in Indonesia.

\section{RESULTS OF STUDY}

A total of ten customer informants of internet banking users were interviewed to understand the barriers experienced in using internet banking and the loyalty characteristics of customers facing these obstacles. The analysis is conducted on the factors behind the behavior of customers in making decisions and actions to face barriers in using internet banking.

Barriers in using Internet Banking. Informants' perception toward barriers in using internet banking related to 3 types of barriers, they are Security Threat, Accessibility Difficulty, and Difficulty in Operating internet banking. Basically, the perceived barrier of informants in using internet banking is the inability or failure to use internet banking.

Security is an important factor in the use of internet banking as customer does not directly meet face to face with bank officials; transaction goes through the technology. Customer trust is created when internet banking security is good. The fifth informant and the ninth informant worried about the possibility of internet banking security attack that they did not want to use the fund transfer feature on the bank website, they only use the features of balance check and account mutation. The fifth informant explained his concern about the occurrence of internet banking hacking which some smart criminals use internet to do crime. The ninth informant explained that fund transfer feature on bank website is not used because of fear of the rampant crime action with information technology that can befall on him, for example the theft of personal data. He performed funds transfers done through ATM machine.

Reliability is ability of internet banking to be available properly, or services consistent with the rules. Several informants explained that problems encountered in using internet banking service are slow access of bank websites, sometimes breaking the bank's website connection, pending transactions, unavailability of transactions proof in real time. The barriers are perceived by most informants except the second informant.

The informants' comments are as follows: "I used internet banking, the problem is that the internet used to have trouble or access is slow, caused by internet provider" (informant 1), "the obstacle to communication sometimes access bank website broken, or signal problem, yet I do not have the will to stop using internet banking, the cause is sourced from the communication/signal of the device used" (informant 3). "Sometimes I have difficulty access internet banking, meaning the system down, for example when I have input data and system down then I have to repeat again enter data, the cause is on the bank" (informant 4).

Several other informants also complained about the slowness of internet banking access: "I often experience the problem of loading, sometimes it is fast sometimes or even access break when using internet banking, the cause is internal of the bank (informant 5)." The problem is on internet connections. I also experienced a delayed transaction, the cause of the tools used such as gadgets and the internet, the cause was also from the bank at certain hour where transactions are high, making internet access slow"(informant 6)." The problem is sometimes the signals in particular location so they cannot access internet banking" (informant 7). "There is a sluggish access to bank websites, the cause is slow internet connection or maintenance of the website of the bank, or the laptop used to access internet banking is infected by the virus" (informant 8). "The broken access was caused by the device used to access the bank website" (informant 9). "I've had problems signaling, if the transaction is over $9 \mathrm{pm}$, I can see the proof of the transaction on the next day, the cause of the bank website and mobile phone card" (informant 10). 
The explanation from the informants above indicates slow or broken access which may be caused by a disruption of customer's device, high internet traffic, bank website accessed by customers at a certain time, or maintenance of the bank's website. Several informants were able to identify what caused the obstacles, and then determine the solutions and actions to overcome obstacles.

The first informant informed difficulty of using internet banking token device to conduct transactions. This situation is considered as a constraint factor as the informants' convenience in using internet banking decrease. These informants then decided to use ATM only.

Token device is a device used in internet banking transactions; bank will automatically send a unique token code for one transaction to the customer's token device. Some banks use token devices in the form of client's mobile communications devices. This token code is confidential data known only to customers who make transactions and is a form of transaction security.

Characteristics of Customer Loyalty in the face of barriers using Internet Banking. Customers face obstacles in using internet banking by leaving it, restricting its use or finding solutions to overcome these obstacles.

Informant 1 left internet banking, then switched to use ATM machine to make money transactions due to difficulty to use internet banking transaction support tools. This action can also happen to other customers. The informant 1 explained "I use ATM machine because it is difficult to use a token device, so for better fund transfer using ATM machine only". This customer behavior is categorized as Low Loyalty.

Limitation of using internet banking is caused by concerns about possible internet banking security risks. Informant 5 explained "I do not want to transfer funds. I just do check balances because there are external factors that can disrupt the hacker attack". Informant 9 explained "the rampant crime allows my personal data known, so I use internet banking to balance check only, to transfer funds I use ATM facility". The characteristics of these customers behavior are categorized Medium Loyalty.

Some informers who experienced slow internet banking connection or disconnection of internet banking tried to find a solution. There are 2 kinds of solutions; the first solution is handling the obstacles independently/alone because of their awareness that the factor came from the device they use, for example when the internet banking connection broke up, the informant restarted by logging-out and re-log in the bank website. The second solution is communicating it to the bank for immediate service improvements. These customer behavior characteristics are categorized as High Loyalty.

"I could not make transactions when the connection was disconnected, then I came to the bank to asked the officer what happened" (informant 3). "when the internet connection broke up, sometimes there was information on the bank's website that the bank system was down again, so I waited for a while, I logout and login again, the internet banking worked" (informant 4). "Delayed transactions sometimes occurred over $9 \mathrm{pm}$, I waited until the next day and obtained information from the bank website that the transaction has happened, if internet banking connection was slow, I prefer to change my gadget" (informant 6). "The broken access was caused by my gadget; I replaced the old devices with better new devices to access internet banking" (informant 9).

Based on the barriers experienced by informants and the behavior of informants facing the obstacles, there are several factors that lie behind the customer's behavior, they are Knowledge, Risk Perception, and other service Choices.

Customer knowledge is a factor behind the behavior of the customers in facing the obstacles of using internet banking. For example, informant 4 overcome the obstacles experienced by logging-out from the bank's website then re-login to recover. The slow internet banking access is by high traffic of bank's website at certain hours causing it to be slow. Likewise, informant 6 decided to replace his gadget as a solution based on his knowledge that the slow access problem using internet banking is not always caused by the bank but also can be caused by the gadget used by informants who have low ability. 
Concerns about the risk of possible security breaches such as malicious hacker attacks on internet banking services prompted Informant 5 and 9 to decide to limit themselves using internet banking feature. The two informants did not use any more funds transfer facilities via internet banking. They only use check balance feature or the account mutation check, they were worried about the dumping of their personal data by malicious hackers.

The influence of other service options such as ATMs, SMS banking, or other internet banking services may encourage customers to prefer to use these other services rather than using internet banking of a bank with problems or obstacles. The goal is to enable customers to make transactions electronically, as experienced by the 1 st informant decided to switch to the use of ATMs to make money transactions.

\section{RESULTS AND DISCUSSION}

Customer's knowledge is one of the factors that shape their behavior so as to enable customers to find solutions to the constraints faced. However, limited knowledge is also a factor that encourages customers to choose to move to other service options such as ATM. According to Aslam et al (2011), knowledge gap affects low adoption of internet banking. Customers with high loyalty characteristics are characterized by the ability to find solutions supported by adequate knowledge and learning skills, so they stay afloat to use internet banking optimally.

The risk perceived by customers as a possible security disturbance can influence the customer's decision to restrict them in using internet banking, for example, customers use internet banking only to check the balance, not for transfers. According to Agwu (2015) the perceived risk of customers is the risk of losing money due to mistakenly using of internet banking. According to Munusamy et al (2012) the perceived risk of customers can threaten customers leaving internet banking services.

In this study, the perceived risk of informants encouraged them not to leave using internet banking; they only limit the use of the features as the informants understood the benefits to be obtained from internet banking. Financial risk stems from threats to hacking crimes that can be performed by people who have ability to break through internet banking (Aslam et al, 2011). Customers with modest loyalty characteristics are characterized by an attitude that is based on concerns about security threats that they reduce the use of internet banking only for the purposes of checking balances or checking account mutations.

An alternative choice of other services may influence customers choosing to use other services rather than using internet banking with some barriers, such as customers switching to ATMs for transactions because of difficulty in operating token equipment. According to Aslam et al (2011) customers consider the cost compared to the perceived benefits obtained to choose other service alternatives. If internet banking services are perceived to require greater costs such as the difficulty of using internet banking, ATM usage, which is considered easier operation, will be the main consideration of the customer to be able to conduct the transaction. Customers with low loyalty characteristics are characterized as easily influenced by other service options, so they can easily abandon the use of internet banking.

A description of the characteristics of customer are grouped in three categories of High, Medium, Low Loyalty related to the ability of customers in facing the obstacles of internet banking is described in the following table.

Table 1 - Characteristics of Customer Loyalty in Barriers to Internet Banking Adoption

\begin{tabular}{|c|c|c|}
\hline $\begin{array}{l}\text { Type of Customer } \\
\text { Loyalty }\end{array}$ & Customer Behavior & $\begin{array}{l}\text { Factors behind the Customer } \\
\text { Behavior }\end{array}$ \\
\hline High & $\begin{array}{l}\text { Finding solutions to overcome barriers and use internet } \\
\text { banking optimally }\end{array}$ & Knowledge \\
\hline Medium & $\begin{array}{l}\text { Limiting the use of internet banking only for some } \\
\text { features of internet banking }\end{array}$ & Risk Perception \\
\hline Low & $\begin{array}{l}\text { Leaving internet banking usage and switching to another } \\
\text { service }\end{array}$ & $\begin{array}{c}\text { Difficulty in operating internet } \\
\text { banking }\end{array}$ \\
\hline
\end{tabular}


Implications of Bank Management. Bank as an internet banking provider has an obligation to improve services for their customers. Therefore, the perceived obstacles of customers in using internet banking become important inputs for Bank Management to improve the service that the barriers can be overcome or minimized.

Unreliability of internet banking, if it is caused by problem in the use such as slow or disconnected access, should be immediately communicated to the customer. Difficulty in using about internet banking security disturbance can be pursued by bank management through the correct education program that customer can overcome barrier of using internet banking appropriately. This educational program can be performed through educational videos on bank website, frequently asked via email correspondence or online chat, educational information through brochures, and explanations from customer service and call center.

Bank must have procedures to detect customer's perceived barriers, determine measures to overcome these barriers, and measure how the measures are taken effectively to resolve problems faced by customers in the use of internet banking. The procedure for handling customer barriers has become a tool for bank management to keep improving its services. Bank management should build an excellent security system to make customers trust in using internet banking (Akram and Asghar, 2012). In addition, Bank Management should be able to establish good communication with customers for good response affects customer satisfaction significantly (Doost and Ashrafi, 2014). Similarly, the ability of banks to manage the security of privacy information can also increase public trust (Irabatti, 2013). Bank management must also be able to manage priority issues to improve the quality of customer service (Ma, 2012).

\section{CONCLUSION AND SUGGESTIONS}

There are three types of obstacles faced by customers in internet banking usage: difficulty of using internet banking, security disturbance, and unreliable access. The customer's response to these obstacles is manifested into three types of behavior, leaving internet banking categorized as low loyalty, limiting themselves in using internet banking features categorized as medium loyalty, and finding solutions to overcome barriers categorized as high loyalty. The three behaviors are influenced by three factors including customer knowledge, risk perception, and influence of other service choice.

Further research can be carried out in finding out how bank as internet banking provider overcome the obstacles perceived by the customers. Further research with quantitative methods is still possible to determine the significance of knowledge, perceptions of risk, and the influence of other service choices on customer decisions in overcoming barriers using internet banking.

\section{REFERENCES}

1. Al-Fahim, N.H. (2013). An Exploratory Study of Factors Affecting the Internet Banking Adoption. Global Journal of Management and Business Research, 13(8): 22-32

2. Al-Smadi, M.O. (2012). Factors Affecting Adoption of Electronic Banking: An Analysis of the Perspectives of Banks' Customers. International Journal of Business and Social Science, 3(17): 294-309

3. Agwu, M. Edwin. (2015). Analysis of Obstacles to Uptake of Internet Banking Services in Nigeria. Research Journal of Business and Management, 2(1): 99-114

4. Akram, S. dan N. Asghar. (2012). An empirical analysis of Customer Satisfaction on adoption of internet banking in Pakistan. ljcrb.com, 3(9): 1124-1132

5. Aslam, H. D., M. Khan, A. Tanveer, T. Amber. (2011). Perceived Barriers Towards Adoption of Internet Banking Among Non-Metropolitan Internet Users of Pakistan. International Business \& Economics Research Journal, 10(4): 45-56

6. Davis, F. D. (1989). Perceived Usefulness, Perceived Ease of Use, and User Acceptance of Information Technology. Journal of MIS Quarterly, 13(3): 319-340 
7. Doost, H. V. dan A. Ashrafi. (2014). Relationship of Online Service Quality with Customer Satisfaction in Internet Banking case study: Pasargad Bank. International Journal of Economy and Social Science (wwww.tijournals.com), 3(1): 130-135

8. Eze, U.C., L.H. Yaw, \& J. K. Manyeki, L.C. Har. (2011). Factors Affecting Internet Banking Adoption among Young Adults: Evidence from Malaysia. International Conference on Social Science and Humanity IPEDR, 5: 377-381

9. Irabatti, P. A. (2013). Customer Satisfaction of Online Banking ini SBI and IClCl-a Comparative Study in Pune City. International Journals of Techno-Management Research, 1(1): 1-14

10. Lee, M. (2009). Factor Influencing the adoption of internet banking: An Integration of TAM dan TPB with perceived risk and perceived benefit. Electronic Commerce Research and Applications, 8(3): 130-141

11. Ma, Z. (2012). Factors Affect the Customer Satisfaction of Internet Banking: an Empirical Study in China. Journal of Convergence Information Technology, 7(3): 101-109

12. Munusamy, J., S. Annamalah, S. Chelliah. (2012). A Study of Users and Non-Users of Internet Banking in Malaysia. International Journal of Innovation, Management and Technology, 3(4): 452-458.

13. Perkins, E.D., \& J. Annan. (2013). Factors affecting the Adoption of Online Banking in Ghana: Implications for Bank Managers. International Journal of Business and Social Research (IJBSR), 3(6): 94-108

14. Saeidipour, B., H. Ranjbar, \& S. Ranjbar. (2013). Adoption of Internet banking. IOSR Journal of Business and Management (IOSR-JBM), 11(2): 46-51

15. Waithaka, S.T. \& K.M.J Nzeveka. (2015). Customers Perception on Ease of Use of Internet Banking in Commercial Banks in Kenya. International Journal of Novel Research in Marketing Management and Economics, 2(2): 66-74 